Мухіна $\Lambda$. Компаративний анаміз виконавських технік ...

УДК 78.034(477.61/62)

DOI https://doi.org/10.24919/2308-4863/34-3-8

Лариса МУХІНА, orcid.org/0000-0002-2381-7297 аспірант, викладач сольного співу кафедри хорового диригування, вокалу та методики музичного навчання Сумського державного педагогічного університету імені А. С. Макаренка, викладач-методист сольного та хорового співу

Сумської дитячої музичної школи № 2, соліст-вокаліст

Сумської обласної філармонії (Суми, Україна) Lorele_a@ukr.net

\title{
КОМПАРАТИВНИЙ АНАЛІЗ ВИКОНАВСЬКИХ ТЕХНІК ПРОВІДНИХ ПРЕДСТАВНИКІВ ВОКАЛЬНИХ ШКІЛ СХОДУ УКРАЇНИ (КІНЕЦЬ ХІХ - ПОЧАТОК ХХ СТОЛІТЬ)
}

У статті окреслені особливості виконавських технік провідних представників вокальних шкіл Сходу України.

Важливість вибору теми даного дослідження обтрунтована відсутністю системного осмислення повної картини феномену виконавських технік провідних представників вокальних шкіл Сходу Украӥни (кінець ХІХ-початок ХХ століть).

Встановлено, щзо загальний фон професійної підготовки академічних вокальних виконавців сформувався на території нашої країни наприкінці XIX - на початку XX століття. Тодішня влада сприяла викладанню в мистецьких навчальних закладах, у т. ч. на території нинішнього Сходу Украӥни, найкращих представників іменитих вокальних икіл Свропи, насамперед з Італії.

Виявлено, щуо своєрідність іноземних запозичень у формуванні виконавських технік у Київській вокальній школі проявлялася в жанровій своєрідності, ритмічі, змісті, емочійності, використанні регістрів голосу, ролі слова в музииі. Оскільки багато представників викладацького складу Одеської школи були іноземиями й досконало володіли італійською, німецькою, іспанською, англійською, франиузькою, польською та іншими мовами, вони використовували в роботі над твором не його переклади, а оригінальний виклад. Вокально-виконавський стиль співу в рамках Харківської вокальної школи характеризувався рівністю голосу по всьому діапазону, красотою тембру, абсолютним контролем дихання, яскравою віртуозною технікою, а також умінням імпровізувати. Спільною рисою всіх східноукрайнських вокальних шкіл було старанне, довге й детальне опрачювання кожного твору, осмислене поєднання художнього задуму та вокальної техніки, а також акиент на самостійній роботі вихованиів школи. Зазначена тема має ряд перспективних напрямів дослідження, у т.ч. висвітлення еволюиї Київської, Одеської та Харківської вокальних шкіл протягом не лише початку, а й усього ХХ століття. Крім того, иікавим міг би стати аналіз зворотного впливу, який здійснювали східноукраӥнські вокальні школи на вокальне мистецтво Свропи.

Ключові слова: виконавські техніки, вокальне мистецтво, вокальна школа, оперний спів, освіта, виконавство, Схід України. 
Larysa MUKHINA, orcid.org/0000-0002-2381-7297

Postgraduate Student, Teacher of Solo Singing at the Department of Choral Conducting,

Vocal and Methods of Music Education

Sumy State Pedagogical University named after A. S. Makarenko,

Teacher-Methodist of Solo and Choral Singing

Sumy Children's Music School № 2,

Soloist-Vocalist

Sumy Regional Philharmonic Society

(Sumy,Ukraine) Lorele_a@ukr.net

\section{COMPARATIVE ANALYSIS OF PERFORMANCE TECHNIQUES OF THE LEADING REPRESENTATIVES OF VOCAL SCHOOLS OF EASTERN UKRAINE (LATE 19 ${ }^{\mathrm{TH}}$ - EARLY 20 ${ }^{\mathrm{TH}}$ CENTURIES)}

The article outlines the peculiarities of performing techniques of leading representatives of vocal schools of East Ukraine. It has been established that the general background of professional training of academic vocal performers formed in the territory of our country at the end of the 20th century - in the beginning of the 20th century. The article outlines the features of performance techniques of the leading representatives of vocal schools of Eastern Ukraine. The then authorities facilitated teaching in artistic educational institutions, including in the territory of the current East of Ukraine, the best representatives of eminent vocal schools in Europe, especially from Italy. It has been revealed that the specificity of foreign borrowing in the formation of performing techniques at the Kiev Vocal School was manifested in genre specificity, rhythm, content, emotionality, the use of voice registers, the role of the word in music. Since many representatives of the teaching staff of Odessa School were foreigners and were perfectly proficient in Italian, German, Spanish, English, French, Polish and other languages, they used the original statement in the work on the work not its translations. Vocal-performing style of singing within the Kharkov vocal school was characterized by level of voice across the range, beauty of timbre, absolute control of breathing, bright virtuoso technique, as well as ability to improvise. A common feature of all Eastern Ukrainian vocal schools was the diligent, long and detailed processing of each work, the meaningful association of artistic design and vocal technique, as well as the emphasis on the independent work of pupils of the school. The importance of choosing the topic of this study is justified by the lack of consistent understanding of the full picture of the phenomenon of performing techniques of the leading representatives of vocal schools in Eastern Ukraine (late $19^{\text {th }}$ - early $20^{\text {th }}$ centuries). This topic has a number of promising areas of research, including coverage of the evolution of Kyiv, Odesa and Kharkiv vocal schools not only during the beginning, but also throughout the $20^{\text {th }}$ century. In addition, an analysis of the repercussions of Eastern Ukrainian vocal schools on European vocal art could be interesting.

Key words: performing techniques, vocal arts, vocal school, opera singing, education, performance, East of Ukraine.

Постановка проблеми. Важливість вибору теми даного дослідження обгрунтована відсутністю системного осмислення повної картини феномену виконавських технік провідних представників вокальних шкіл Сходу України (кінець XIX - початок XX століть). Водночас східноукраїнські вокальні школи сольного співу, класичний вигляд яких сформувався саме в означений період, наразі займають вагоме місце з-поміж інших осередків міжнародної традиції академічного вокалу. У своєму усталеному вигляді східноукраїнські школи сольного співу сформувалися на території нашої країни в період творчої діяльності таких видатних діячів, як Б. Гмиря, М. Донець-Тессейр, Д. Свтушенко, О. Мишуга, О. Муравйова, I. Паторжинський.

3 огляду на зазначене особливої ваги набуває порівняльний аналіз різних виконавських технік у вокальних школах у східних регіонах нашої країни.
Розвиток виконавських технік вокального мистецтва у рамках певних шкіл пов'язаний із низкою наукових дисциплін, зокрема: культурологією, історією музичного мистецтва й вокального виконавства, філософією і теорію мистецтва співу тощо.

Аналіз досліджень. Серед окремих наукових розвідок відносно виконавських технік професійної вокальної освіти на території України на рубежі XIX і XX століття слід виділити монографії та публікації таких дослідників, як Б. Гнидь (Гнидь, 1997), Ю. Грищенко (Грищенко, 2010), А. Желан (Желан, 2004: 84-87), І. Малиніна (Малиніна, 2000: 19-20), М. Мельник (Мельник, 2019), Д. Оленюк (Оленюк, 2009: 271-277), Р. Шмагало (Шмагало, 2013).

Метою статті $\epsilon$ систематизація й узагальнення відомостей про виконавські техніки провідних представників вокальних шкіл Сходу України 
(кінець XIX - початок XX століть) у безпосередньому зв'язку з розвитком вказаних технік у провідних країнах Свропи, зокрема в Італії (техніка «бельканто»).

Об'єктом дослідження даної публікації є розвиток вокальних шкіл Сходу України в період на межі XIX - XX ст. Предметом дослідження являються відмінності у виконавських техніках професійних вокальних шкіл в Україні на межі XIX - ХХ століть.

Виклад основного матеріалу. Серед наукових дефініцій поняття «вокально-педагогічна школа» досить вдало пропонує Дмитро Аспелунд: «це «конкретна, цілеспрямована, організована система підготовки нових поколінь співаків та педагогів для конкретної діяльності, що історично змінюється» (Аспелунд, 2016: 4). Відповідно до ще одного визначення, висунутого Б. Гнидем у монографії «Історія вокального мистецтва», «таке поняття можна вживати як визначення української, італійської, французької, німецької, російської, болонської та ін. вокальних шкіл. Вокальна школа історично змінна, соціальна та національна. Процес історичної змінності вокальних шкіл завжди нерозривно пов'язаний з історичним розвитком музики, 3 конкретними вимогами виконавської практики. Соціальні умови визначають ідейну та естетичну направленість вокального мистецтва, а також впливають на характер вокальних шкіл. Національний характер вокальних шкіл зумовлений складом життя кожного народу: його поезією, законами фонетики, мови, народними традиціями в музиці, мистецтвом народних співаків» ((Гнидь, 1997: 3).

Період становлення вокальних шкіл у Західній Європі відноситься до XVII ст., що більше ніж на 200 років випереджає Україну. Вказане пов'язано 3 розвитком композиторських шкіл, які вимагали створення відповідного вокального виконавського контексту (Оленюк, 2009: 274). Загальновідомо, що провідну роль у цьому процесі відігравала Італія, де сформувалися основи оперного співу в його нинішньому розумінні (Оленюк, 2009: 271). Також тут створювалися й відповідні виконавські школи.

Крім Італії, вокальна педагогіка успішно розвивалася у Франції (представники - Жільбер Луї Дюпре, Мануель Гарсіа-син) й Німеччині (Р. Вагнер, Ю. Гей, Ф. Шмітт, Ю. Штокгаузен). При цьому в рамках німецької школи заперечувався італійський метод навчання співу, натомість ураховувалися специфічні особливості оперної німецької музики й фонетики німецької мови. На підставі них створювалися німецькі вокальні школи. Однак німецькі вокалісти все одно зверта- лися до італійських практик. Так, Ф. Шмітт заперечував «прикриття» верхньої ділянки діапазону голосу (його метод дістав назву «школа прімарного тону», оскільки вживалося італійське слово «prima» - перший, тобто найкращий тон голосу) (Шуляр, 2012: 155).

Загальний фон професійної підготовки академічних вокальних виконавців сформувався на території нашої країни наприкінці XIX - на початку XX століття. Тодішня влада заохочувала викладання в мистецьких навчальних закладах, у т. ч. на території нинішнього Сходу України, найкращих представників іменитих вокальних шкіл Свропи, насамперед з Італії.

Говорячи про географічні особливості розвитку вокальних шкіл наддніпрянської України на межі позаминулого й минулого століть, слід насамперед виділити такі потужні центри, як Київ, Одеса і Харків. У досліджуваний період у цих містах відкривалися опери й музичні школи, що вимагало розвитку відповідної освітянської бази, а також залучення професійних викладацьких кадрів, у т. ч. 3-за кордону.

\section{Київська школа}

Як відомо, Київське музичне училище було засноване у 1868 році, а консерваторія відкрилася у 1913 р. 3-поміж викладачів співу в музичному училищі в Києві слід виокремити таких відомих оперних виконавців, як А. Барцал, О. ЛисенкоО'Коннор, Ю. Махіна, П. Сєтов тощо. Також на початку XX століття до Києва були запрошені імениті викладачі-італійці - К. Еверарді, М. Петц, Е. Гандольфі.

Основним викладацьким принципом Гектора Гандольфі було заперечення будь-якої напруженості, тобто цілковита природність виконання. Маючи чудовий голос (бас), Г. Гандольфі водночас боявся сцени і більше любив виступати як викладач, а не соліст. Ймовірно, що саме вказаний фактор спричинив перехід цього видатного співака до педагогічної роботи. Він привніс у Київську музичну школу бездоганний музичний смак і водночас високі вимоги до учнів (оскільки домагався, щоби кожен учень у повній мірі з'ясував і правильно виконав його вказівки) (Тиц, 1984: 66-72).

Творчий педагогічний метод Г. Гандольфі полягав у тому, що на початку занять він слідкував за правильною постановою учня, рекомендуючи виконавцям рівно стояти із простягнутими вздовж тулуба руками. Педагог вважав, що саме таке положення співака забезпечує природне грудодіафрагмальне дихання. Г. Гандольфі ніколи особливо не здійснював фіксування увагу учня спеціально на диханні, однак у практичній діяльності 
майже завжди досягав забезпечення правильного співацького дихання в учнів. Іншими вимогами в рамках педагогічного методу Г. Гандольфі були:

- поєднання грудного й головного резонування практично по всьому діапазону голосу (в особливій мірі - на його середньому відрізку);

- забезпечення у меццо-сопрано повного згладжування регістрів та красивого й насиченого обертонами звучання;

- велика увага до округлого критого звучання;

- примушення басів забезпечити прикриття pe-, мі-бемоль та навіть ре-бемоль і до першої октави;

- пропозиція починати гаму на октаву нижче 3 майже закритим ротом (при цьому між губами повинна лишатися лише невелика щілина), для того щоб забезпечити краще відчуття резонування звуку. Потім співаку слід було, підіймаючись по ступенях гами, на верхній ноті широко відкрити рот за вільно відкритої глотки (Тиц, 1984: 66-72).

Г. Гандольфі причетний до формування виконавської майстерності таких співаків, як І. Голянд, В. Гужова, М. Калиновська, С. Капара, О. Колодуб, Є. Кончевський, М. Стефанович тощо. При цьому логічно, що Г. Гандольфі вимагав так званого «італійського» звучання голосу. Звук повинен бути «сконцентрованим» за умови обов'язково яскравої, близької вимови голосних літер. Обов'язковими компонентами «сконцентрованості» звуку Г. Гандольфі вважав те, що звук має бути округлим і прикритим, тобто насичений добре резонуючими обертонами.

Важливий напрям вокальної майстерності в рамках Київської школи був сформований О. Мишугою (серед більше ніж 50-ти його учнів - М. Висоцька, М. Гребінецька, В. Долинська, М. Микиша, С. Мирович, Л. Морозовська, О. Любич-Парахоняк, І. Сологуб-Бокконі, В. Ціхович, I. Шмеркович, Є. Штрассерн).

Відповідно до підходу О. Мишуги, підготовка майбутнього співака мала передбачати прищеплення виконавцю розуміння правильного вокального тону. На думку викладача, оскільки визначальна роль у вокальному мистецтві належить інтерпретації, справді виразний спів так само $є$ неможливим без постановки співочого голосу, який би характеризувався сильною інтонацією. Без цього високохудожня інтерпретація твору видавалася для О. Мишуги неможливою. Педагог дотримувався переконань, що навіть найбільш щире прагнення не призведе до досконалого виконання, якщо голос сформований неправильно. Будучи, як і його італійські колеги, вимогливим і суворим до інтонаційних похибок,
О. Мишуга водночас не терпів у співі нещирості й вимагав від своїх учнів технічної досконалості, а також шляхетності, тепла, глибини почуттів $\mathrm{i}$ сердечності виконання.

Під поняттям технічної досконалості О. Мишуга мав на увазі таке:

«Щоби правильно співати,

Треба добре вимовляти

Кожну букву в кожнім слові

Так, як вимовляють в мові,

Но не горлом, а губами,

Пред язиком, за зубами,

Піднебіння вверх стягати

І в самих вустах співати»

(Головащенко, 2004: 26, 51-58).

Таким чином, викладач наполягав на дуже чіткій вимові кожного слова під час співу. Крім того, заняття в Музично-драматичній школі М. Лисенка О. Мишуга вів виключно українською мовою, що на той час було вельми сміливим вчинком. Вокальна школа О. Мишуги стала базисом для його власної педагогічної методики, яка згодом була творчо розвинута в Київській консерваторії М. Донець-Тессейрою і М. Микишою.

Інший представник Київської вокальної школи О. Пилипович дотримувався підходу до формування виконавських технік вокалістів, який передбачав такі складники:

- на початковому етапі підготовки - надзвичайна послідовність і строгість у розвитку вокальної техніки;

- недопущення найменшого відхилення від виконання учнями завдань, нетерпимість до помилок;

- формулювання чітких і зрозумілих вимог до звучання голосу.

Одеська школа

Майже одночасно з Київською була заснована Одеська консерваторія (1913 рік, перший ректор - В. Малішевський). Ї̈̈ керівництво, так само як і в Києві, додержувалося політики залучення видатних іноземних педагогів вокального мистецтва (не лише Італія, але й Австро-Угорщина). Серед викладачів Одеської вокальної школи Д. Дельфіно-Менотті, Б. Дронсейко-Миронович, Й. Перман, Ю. Рейдер, Ф. Ступка.

Оскільки, як бачимо, багато представників викладацького складу Одеської школи були іноземцями й досконало володіли італійською, німецькою, іспанською, англійською, французькою, польською та іншими мовами, вони використовували в роботі над твором не його переклади, а оригінальний виклад. Власне, того ж вони вимагали і від своїх учнів. 
Італійські викладачі Одеської школи (наприклад, Д. Дельфіно-Менотті) ставили перед учнями такі вимоги:

- використання округлого критого звучання на стійкій опорі дихання для тренувального співу старовинних італійських канцонеток, нескладних класичних арій;

- «відточування» техніки співу насамперед із більш підготовленими учнями;

- робота над філіруванням вокального виконання (ця вправа називалася «парасолька»), коли всі однотипні голоси співали витриману ноту -3 піаніссімо 3 поступовим доведенням до фортіссімо;

- забезпечення виразності з використанням справжніх емоцій і переживань;

- проходження з учнями великого репертуару.

Харківська школа

Формування Харківської вокальної школи безпосередньо пов'язане з іменем I. Слатіна, котрий у свою чергу здобув освіту в стінах Берлінської нової академії музики. Запрошуючи до Харкова представників відомих європейських мистецьких шкіл викладачами, він користувався значним авторитетом у творчій спільноті Харкова, будучи знайомим із М. Римським-Корсаковим, П. Чайковським, братами Рубінштейн тощо.

Випускники Харківської консерваторії (співаки В. Арканова, О. Востряков, Б. Гмиря, Н. Компанієць, М. Манойло, Н. Суржина, В. Третяк, В. Трішин, М. Частій, Г. Ципола) були відомі в Україні й далеко за ії межами.

Серед іï викладачів слід виокремити П. Голубєва, котрий у 1906 році закінчив Харківське музичне училище по класу Ф. Бугамеллі, а 31908 по 1926 роки викладав у цьому училищі. П. Голубєв був переконаний, що «у процесі співу бере участь не тільки голосовий апарат; не буде перебільшенням вираз «співає весь організм» у повній гармонії всіх його фізичних, емоційних і творчих можливостей» (Голубев, 1956: 32). На його думку, правильно сформований голос співака має певні властивості: округлений, опертий, близький і рівний у всіх регістрах звук, мішане грудо-головне резонування його на основі нижньо-реберно-діафрагмального (костоабдомінального) дихання. На переконання П. Голубєва, подібний звук має відповідати запитам сучасних слухачів.

Професор стверджував таке: «Опора дихання й опора звука, крім благотворного впливу на саму якість співацького звуку, ще й знімають зайве напруження 3 гортані та голосових зв'язок і передають його в потужну систему витривалих м'язів - вдихачів і видихачів» (Голубев, 1956: 38).
Як вважає П. Голубєв, сучасна школа округленого, близького й опертого звуку є результатом погодженої комплексної роботи всіх компонентів голосового апарату, і це дозволяє забезпечити досягнення оптимальних показників із найменшими витратами енергії та гарантує здоровий стан співака. На думку викладача, мистецтво співацького дихання передбачає не лише кількість повітря, яке вдихається в легені, а найважливіше - уміння еластичного сповільненого видиху, який регулюється м'язами-видихачами. Важливе значення викладач Харківської школи надавав питанню опори звука, тобто взаємодії між ступенем скорочення голосових зв'язок і відповідним підзв'язковим повітряним тиском.

У Харківській школі розповсюдилася техніка співу «бельканто» (iт. «belcanto» - «прекрасний спів»). Цей вокально-виконавський стиль співу характеризувався такими рисами:

- рівністю голосу;

- красотою тембру;

- володінням кантиленою;

- абсолютним контролем дихання (filarilsuono);

- умінням імпровізувати.

Різні складники «бельканто» чинили взаємний вплив, розвивались синхронно, визначаючи при цьому динаміку оперного жанру в Україні.

Одним 3 іноземних викладачів Харківської школи був К. Еверарді, котрий закінчив Паризьку консерваторію по класу співу і мав бас-баритон величезного діапазону, що дозволяло йому працювати як із баритоновим, так і з басовим репертуаром. Він вважав основою якісного «бельканто» правильне співацьке дихання, а також рекомендував абдомінальний тип дихання (глибокий вдих через ніс і рот одночасно, миттєва затримка дихання перед атакою звука, а потім - повільний, поступовий, ненапружений видих).

К. Еверарді вимагав від своїх учнів забезпечення положення корпусу, гортані, нижньої щелепи й рота у вільний спосіб, без будь-якого напруження. Крім того, він прагнув добиватися вироблення хорошої кантилени - легато, що мало бути подібним до звука віолончелі чи скрипки. Його учні мали оволодіти як форте, так і піано, а також філірування й легким та швидким портаменто. Вважаючи принциповим оволодіння всіма прийомами вокальної техніки, К. Еверарді найбільшого значення надавав дикції, тобто чіткій і правильній вимові голосних, а також підкресленому (тобто подвоєному чи потроєному) відтворенню приголосних. Вимагаючи бездоганно точного розуміння авторського тексту, К. Еверарді прагнув значної виразності виконання, завжди 
підкреслюючи те, що голос не є головним чи єдиним компонентом у комплексі даних вокаліста. Він вважав, що, маючи несильний або не дуже красивий голос, але володіючи мистецтвом перевтілення, а також акторською й вокальною технікою, виконавець зможе бути кращим артистом, ніж вокаліст із сильним, але беззмістовним голосом.

Якісно поставленим голосом К. Еверарді вбачав змішане грудне й головне резонування, що грунтувалося на головному звучанні на низьких грудному звучанні на високих нотах. Його сильною стороною була робота над треллю (він вимагав точної трелі на 2-х нотах). Від учнів він вимагав багатомісячної роботи над вокалізами і лише потім дозволяв перейти до співу зі словами.

Враховуючи плідний взаємообмін методиками викладання і виконання у сфері вокального мистецтва між східно- й західноукраїнськими вокальними школами, слід зазначити про вокальну техніку С. Крушельницької, яка представляла Львівську школу, проте ii виконавська техніка широко використовувалася і викладачами співу на Сході. Оскільки вона володіла так званим «шаляпінським секретом», тобто «інтонацією душевного стану» (або «інтонацією подиху»), її виконавська техніка грунтувалася на перевтіленні в персонаж, партія якого виконувалася в даний момент, a також проникненні в його душевний стан.

Усім східноукраїнським професійним вокальним школам України було притаманне комплексне поєднання теорії 3 практикою (відбувалося активне відкриття оперних театрів). Водночас професіоналізація освіти сприяла активізації музичної й вокальної культури суспільства.

Висновки. Отже, загальний фон професійної підготовки академічних вокальних виконавців сформувався на території нашої країни наприкінці XIX - на початку XX століття. Тодішня влада заохочувала викладання в мистецьких навчальних закладах, у т. ч. на території нинішнього Сходу України, найкращих представників іменитих вокальних шкіл Свропи, насамперед 3 Італії. Так, на початку XX століття до Києва були запрошені імениті викладачі-італійці К. Еверарді, М. Петц, Е. Гандольфі.

Своєрідність іноземних запозичень у формуванні виконавських технік у Київській вокаль- ній школі проявлялася в жанровій своєрідності, ритміці, змісті, емоційності, використанні регістрів голосу, звуковеденні, ролі слова в музиці, мелізматиці, а також ладовій структурі. Так зване «італійське» звучання голосу передбачало те, що звук повинен бути «сконцентрованим» за умови обов'язково яскравої й близької вимови голосних літер.

Як і в Києві, багато представників викладацького складу Одеської школи були іноземцями, що передбачало їхній досконалий рівень володіння італійською, німецькою, іспанською, англійською, французькою, польською та іншими мовами. Таким чином, викладачі в Одесі використовували в роботі над твором не його переклади, а оригінальний виклад (і вимагали того ж від своїх учнів).

Вокально-виконавський стиль співу, сформований викладачами в рамках Харківської вокальної школи, характеризувався рівністю голосу на всьому діапазоні, красотою тембру, володінням legato, абсолютним контролем дихання, яскравою віртуозною технікою, а також умінням імпровізувати. Викладачі Харківської школи вважали, що студент-вокаліст має володіти не тільки співацьким голосом, музичним слухом, почуттям ритму, але й виконавською обдарованістю й загальною культурою, а також відповідним інтелектом, здібностями щодо сприйняття вказівок педагога і організованою психікою, тобто сильним характером студента.

I Київська, і Одеська, i Харківська школи сольного співу характеризувалися глибоким національним корінням і синтезом характерних рис західноєвропейської (зокрема італійської) та української методик вокального виконання. Спільною рисою всіх східноукраїнських вокальних шкіл було старанне, довге й детальне опрацювання кожного твору, а також акцент на самостійній роботі учнів та їхній старанній самостійній роботі.

Зазначена тема має ряд перспективних напрямів дослідження, зокрема, у плані висвітлення еволюції Київської, Одеської й Харківської вокальних шкіл протягом не лише початку, а й усього XX століття. Крім того, цікавим міг би стати аналіз зворотного впливу, який здійснювали східноукраїнські вокальні школи на вокальне мистецтво Свропи. 


\section{СПИСОК ВИКОРИСТАНИХ ДЖЕРЕЛ}

1. Аспелунд Д. Развитие певца и его голоса. Санкт-Петербург : Лань, Планета музыки, 2016. 180 с.

2. Гнидь Б. П. Історія вокального мистецтва. Київ : НМАУ, 1997. 320 с.

3. Голубев П. В. Советы молодым педагогам-вокалистам. Москва : Музгиз, 1956. 104 с.

4. Грищенко Ю. В. Розвиток професійної вокальної освіти в Україні (кінець XIX - початок XX ст.). Житомир, 2010. $24 \mathrm{c}$.

5. Желан А. Вплив видатних педагогів на розвиток музично-культурного середовища Миколаївщини кінця XIX початку XX століть. Теоретико-методичні проблеми виховання учнів загальноосвітніх шкіл. Київ : Інститут проблем виховання АПН України, 2004. С. 84-87.

6. Людкевич С. Олександр Мишуга як артист і вчитель співу. Дослідження, статті, рецензї, виступи. Львів : Вид-во М. Коць «Дивосвіт», 1999. Т. 1. С. 430-438.

7. Малиніна I. О. Школи образотворчого мистецтва України кінця XIX - початок XX ст. Матеріали науковопрактичної конференції молодих вчених за 2000 рік. Харків : Харківський державний педагогічний університет ім. Г. С.Сковороди, 2000. С. 19-20.

8. Мельник М. Т. Стиль: поняття та специфіка прояву в моді. URL: http://vuzlib.com/content/view/1560/62 (дата звернення: 02.11.2019).

9. Оленюк Д. В. Західноєвропейська вокальна традиція та їі вплив на українську культуру оперного співу (XIX початок ХХ століття). Актуальні проблеми історії, теорії та практики художньої культури : зб. наук. пр. ; М-во культури і туризму України, Держ. акад. кер. кадрів культури і мистец., Київ. нац. ун-т ім. Т. Шевченка. Київ : Міленіум, 2009. С. 271-277.

10. О. Мишуга - король тенорів / авт.-упор. М. Головащенко. Київ : Муз. Україна, 2004. С. 51-58.

11. Тиц Г. И. Мой учитель Э. Гандольфи. Вопросы вокальной педагогики. Москва : Муз., 1984. Вып. 7. С. 66-72.

12. Шмагало Р. Т. Мистецька освіта й мистецтво в культуротворчому процесі України XX-XXI ст. Львів : ЛНАМ; Тернопіль : Мандрівець, 2013. 530 с.

13. Шуляр О. Д. Історія вокального мистецтва. Івано-Франківськ, 2012. 360 с.

\section{REFERENCES}

1. Aspelund D. Razvitie pevca i ego golosa [Development of the Singer and His Voice]. Lan, Planet of Music, SaintPetersburg, 2016. 180 p. [in Russian].

2. Hnyd, B.P. [History of Vocal Art]. NMAU, Kyiv. 1997. 320 p. [in Ukrainian]

3. Golubev, P.V. Sovety molodym pedagogam-vokalistam [Tips for Young Teachers-Vocalists]. Muzgiz, Moscow, 1956. 104 p. [in Russian].

4. Grishchenko, Yu.V. Development of Professional Vocal Education in Ukraine (late $19^{\text {th }}-$ early $20^{\text {th }}$ centuries). Zhytomyr. 2010, 24 p. [in Ukrainian]

5. Zhelan A. Vplyv vydatnykh pedahohiv na rozvytok muzychno-kulturnoho seredovyshcha Mykolaivshchyny kintsia XIX - pochatku XX stolit [The Influence of Outstanding Teachers on the Development of the Musical and Cultural Environment of Mykolaiv Region in the Late $19^{\text {th }}-$ Early $20^{\text {th }}$ Centuries]. Theoretical and Methodological Problems of Education of Secondary School Students. Kyiv: Institute of Education Problems of the Academy of Pedagogical Sciences of Ukraine. 2004, pp. 84-87. [in Ukrainian]

6. Liudkevych S. Oleksandr Myshuha yak artyst i vchytel spivu [Oleksandr Myshuha as an Artist and Singing Teacher]. Research, articles, reviews, speeches. Lviv: M. Kots Dyvosvit Publishing House,, 1999. Vol. 1, pp. 430-438. [in Ukrainian]

7. Malynina I.O. Shkoly obrazotvorchoho mystetstva Ukrainy kintsia KhIKh - pochatok KhKh st. [Schools of Fine Arts of Ukraine in the Late $19^{\text {th }}-$ Early $20^{\text {th }}$ Century]. Proceedings of the Research and Training Conference of Young Scholars for 2000: H.S. Skovoroda Kharkiv State Pedagogical University, Kharkiv, 2000, pp. 19-20. [in Ukrainian]

8. Melnyk M.T. Style: the Concept and Specifics of Manifestation in Fashion. URL: http://vuzlib.com/content/ view/1560/62. (Last accessed: 02.11.2019).

9. Oleniuk D.V. Western European Vocal Tradition and its Influence on the Ukrainian Culture of Opera Singing $\left(19^{\text {th }}-\right.$ Early $20^{\text {th }}$ Century). Aktyalni Problemy Istorii, Teorii ta Praktyky Khudozhnioi Kultury: Collection of Scholarly Works / Ministry of Culture and Tourism of Ukraine, State Academy of Managerial Staff of Culture and Arts, Taras Shevchenko National University of Kyiv: Millennium, Kyiv. 2009, pp. 271-277.

10. O. Myshuha - King of Tenors [O. Myshuha- korol tenoriv] / ed. by M. Holovashchenko. Music of Ukraine. Kyiv, 2004, pp. 51-58. [in Ukrainian]

11. Tytz H.I. Moj uchitel' Je. Gandol'fi [My Teacher E. Gandolfi]. Questions of vocal pedagogy. Moscow Muz., 1984, Is. 7. pp. 66-72. [in Russian].

12. Shmagal R.T. Mystetska osvita y mystetstvo v kulturotvorchomu protsesi Ukrainy KhKh-KhKhI st. [Art Education and Art in the Cultural Process of Ukraine in the $20^{\text {th }}-21^{\text {st }}$ Centuries]. LNAM, Lviv; Mandrivets, Ternopil, 2013,530 p. [in Ukrainian]

13. Shuliar O.D. Istoriia vokalnoho mystetstva [History of Vocal Art]. Ivano-Frankivsk, 2012. 360 p. [in Ukrainian] 